Izv. prof. dr. sc. Željko GALIĆ

Pravni fakultet Sveučilišta u Mostaru

zeljko.galic@pf.sum.ba

Ana LANDEKA, asistentica

Pravni fakultet Sveučilišta u Mostaru

ana.landeka@pf.sum.ba

Ivana DŽIDIĆ, mag. iur.

Centar za informiranje i priznavanje dokumenata

iz područja visokog obrazovanja, Mostar

ivanadzidic24@gmail.com
UDK: 347.772:796 (497.6)

Primljeno: 6. 12. 2021. Prihvaćeno: 19. 12. 2021.

Pregledni znanstveni rad

\title{
PRAVNI PRISTUP VREDNOVANJA SRODSTVA U KONTEKSTU NASILJA U OBITELJI I NEKIH KAZNENIH DJELA U BOSNI I HERCEGOVINI
}

Sažetak: Srodstvo je konstitutivni element i u znatnoj mjeri određujući čimbenik strukture obitelji. Svojom slojevitom biološkom i društvenom sastavnicom na poseban način određuje prirodu i svojstva obitelji i šireg društva. Srodničke i obiteljske odnose obilježava solidarnost, osjećajna bliskost, međusobna ovisnost i povjerenje. Ti oblici povezanosti u većini situacija imaju zaštitničku funkciju i čimbenik su stabilnosti obiteljskih $i$ širih društvenih odnosa, ali ponekad rezultiraju specifičnim oblicima nasilničkog ponašanja i nekih kaznenih radnji.

Autori u radu analiziraju postojeće normativne pristupe problemima nasilja u obitelji i nekih kaznenih djela, koji izravno ili posredno ugrožavaju obiteljsko zajednišstvo i osobna prava. Uočavaju kako zbog životnih poteškoća i složene prirode ljudskog bića, srodnički odnosi ponekad sadrže elemente devijacije i pretvaranja u destruktivne odnose. Navode nastojanja zakonodavaca da s posebnom pažnjom vrednuju $i$ sankcioniraju postupke i radnje unutar srodničkih i obiteljskih odnosa, tako što pojedinim radnjama daju svojstva privilegiranih ili kvalificiranih oblika kaznenih djela.

U svrhu poboljšanja zaštite obitelji i ljudskog života, autori u sklopu teme navode $i$ neke prijedloge de lege ferenda.

Ključne riječi: srodstvo i obitelj; nasilje u obitelji; neka kaznena djela; zaštita ljudskog života, obitelji i društva. 


\section{Uvod}

U povijesnom kontekstu i suvremenim društvima možemo uočiti više oblika srodstva koji povezuju ljudska bića i imaju pravne, gospodarske, religijske, moralne, običajne učinke.

Srodnički odnosi uronjeni su u cijelu povijest ljudskog roda, suodnos obitelji i društva i nastanak društvenih pravila usko su vezani uz srodstvo, a opseg obiteljskih veza dugo vremena se podudarao s dosegom srodničkih učinaka. Pojam srodstva, kao i njegovi društveni učinci, značajno je evoluirao kroz povijest. Iako ono u modernom društvu načelno gubi na značenju, njegovi pravni učinci su i danas itekako važni ${ }^{1}$.

Srodnički odnosi svojim učincima unutar obiteljskih odnosa uglavnom su kohezijski - uzajamni srodnički odnos prema nekoj osobi istodobno jača zajedništvo među takvim osobama, primjerice roditelji odnosno bake i djedovi međusobno; ali ponekad može biti i s učincima u suprotnom smjeru - u situacijama roditeljske skrbi jednog roditelja kojem nije u interesu da dijete ostvaruje susrete $s$ drugim roditeljem.

Prirodu i značenje srodničkih odnosa oblikuju kulturne varijacije, a ono je jedno od temeljnih načela organiziranja pojedinaca u društvene skupine, uloge i kategorije te utječe na širu društvenu strukturu. U većini tradicijskih društava ono je temelj cjelokupne društvene organizacije, određuje prava i obveze pojedinaca i prožima sve aspekte života.

Srodničke i općenito obiteljske odnose obilježava osjećajna bliskost, međusobna ovisnost i povjerenje. Takav oblik povezanosti u većini situacija ima zaštitničku funkciju, ali ponekad rezultira specifičnim oblicima nasilničkog ponašanja i nekih kaznenih radnji.

Iako su srodnički odnosi i s društvenog aspekta iznimno važni i prisutni u ljudskom društvu, o njima je relativno malo pisano izrijekom i izravno. To je zbog više razloga, a jedan od najvažnijih je taj da je analiza obiteljskopravnih odnosa u velikoj mjeri zapravo fragmentarna analiza srodničkih odnosa, tj. prava, dužnosti i obveza koje proistječu iz pravno relevantnih srodničkih odnosa.

\section{Vrste i pravni učinci srodstva}

Srodstvo je uvijek društveni odnos, a za njegovo pravno priznanje u svakoj konkretnoj situaciji potreban je zakonom predviđen način odnosno postupak.

\footnotetext{
$1 \quad$ Usp. Ponjavić, Z., Pravni značaj srodstva, Pravni život, Beograd, 9 (2002.), str. 678.
} 
Domaći zakonodavci, ${ }^{2}$ kao i većina europskih, poznaju tri vrste srodstva - krvno, tazbinsko i adoptivno, a njih određuju načini nastanka, odnosno postojanje određenih činjenica koje stvaraju srodničke veze.

Krvno srodstvo nastaje rođenjem kao veza između osoba koje potječu jedna od druge, ili koje imaju zajedničkog pretka; a ovisno o tome u kakvom obliku životnog zajedništva je nastalo - može biti bračno ili izvanbračno. Ova vrsta srodstva je najzastupljenija u društvu, i pravni poredak mu daje učinke u raznim područjima života i međuljudskih odnosa. Iz njega proistječe obiteljski status i konkretne obveze, prava i dužnosti unutar obitelji i širih društvenih odnosa. Uređuju ga i sankcioniraju gotovo sva zakonodavstva: obiteljsko - tvorbeni je čimbenik nastanka obitelji; građansko - nasljeđivanje; kazneno - propisana djela protiv obitelji i braka; socijalno i stambeno - razna prava i dužnosti; postupovne norme - građanske, kaznene, upravne..., u pogledu ne/mogućnosti pojavljivanja neke osobe u ulozi suca, tužitelja, svjedoka, zapisničara, tumača, vještaka.

Krvno srodstvo kao pravni odnos sadrži biološku i pravnu komponentu. Ako krvno srodstvo nije priznato pravom, ono egzistira samo u svojoj biološkoj komponenti, u objektivnoj stvarnosti, ali bez pravnih učinaka. Ako je pravom priznato, a biološka komponenta se podudara s pravnom - srodstvo egzistira u svojoj punini. Moguća je i treća kombinacija - kada je srodstvo netočno priznato pravom, tj. kad nema biološke komponente - i u tom slučaju postoje pravni učinci srodstva.

U suvremenim okolnostima biološki proces začeća i rađanja nije jedini način nastanka krvnog srodstva - nego je to u znatnoj mjeri ugovorni odnos, volja, pregovaranje, fikcija, institucionalno priznanje. Društvena kontrola nastanka srodstva zamjenjuje se individualnim pravom, čime veza sa srodnicima u velikoj mjeri postaje stvar osobnoga izbora. Voljni element, osim uloge pri zasnivanju srodstva, očituje se i pri nastanku ili prekidu trajanja nekih od pojavnih oblika životnog zajedništva, kod samohranog roditeljstva, sklapanju uzastopnih brakova, kod pojednostavljenog postupka razvoda braka i sl.

Tazbinsko srodstvo nastaje sklapanjem braka i predstavlja pravnu, društvenu i moralnu svezu između jednog bračnog partnera i krvnih srodnika drugog bračnog partnera. U nekim pravnim sustavima ono nastaje i iz drugih oblika životnih zajednica žena i muškaraca. Društveno značenje ovog srodstva temelji se

\footnotetext{
U Bosni i Hercegovini (dalje: $\mathrm{BiH}$ ) postoje tri važeća zakona koji uređuju obiteljskopravne, a time i srodničke odnose: Obiteljski zakon Federacije BiH (dalje: ObZ FBiH), Službene novine Federacije BiH (dalje SN FBiH), br. 35/2005, 41/2005 i 31/2014; Porodični zakon (Republike Srpske) (dalje: PoZ RS), Službeni glasnik RS (dalje: SG RS), br. 54/2002, 41/2008 i 63/2014; te Obiteljski zakon Brčko Distrikta BiH (dalje: ObZ BD), Službeni glasnik Brčko Distrikta BiH (dalje: SG BD), br. 23/2007.
} 
na postojanju „podjele uloga“ u društvu i obitelji, pa uz postojanje onih važnijih - otac, majka, dijete; važnost se daje i ulogama tazbinskih srodnika - svekar, svekrva, nevjesta... Nerazlikovanje tih uloga smatra se nepoželjnim, i to pravni poredak u određenoj mjeri sprječava, sve u svrhu očuvanja i zaštite postojećih bračnih i obiteljskih odnosa, odnosno radi zaštite prava i dobrobiti pojedinih osoba.

Srodstvo iz posvojenja, adoptivno ili građansko srodstvo nastaje pravnim putem - ugovorom ili aktom mjerodavnog državnog tijela. Ovim oblikom srodstva u pravilu se zasniva odnos kakav postoji između roditelja i djece, pa je ono u tom smislu oponašanje krvnoga srodstva. Značenje ovog srodstva se ogleda ponajprije u omogućavanju zbrinjavanja djece bez odgovarajuće roditeljske skrbi; njime nastaju međusobna prava i obveze adoptivnih srodnika (npr. nedopušteno je sklapanje braka između posvojitelja i njegove posvojenice); temelj je za zakonsko nasljeđivanje, kao i za ostvarivanje drugih prava izvan obiteljskih odnosa u užem smislu (socijalna, zdravstvena, mirovinska i druga prava).

Koliki će krug osoba biti obuhvaćen adoptivnim srodstvom ovisi o pravnoj prirodi (konkretnog) instituta posvojenja koji uređuje neki pravni poredak. Tako je adoptivno srodstvo u najširem smislu sveza koja postoji između posvojitelja (adoptans) i posvojenika (adoptatus); te između posvojitelja ${ }^{3}$ i njihovih krvnih srodnika s jedne strane i posvojenika i njihovih krvnih srodnika s druge strane. ${ }^{4}$

U domaćim obiteljskim zakonima svakako bi trebalo izbjeći stanovitu nejasnoću u sadašnjem normiranju adoptivnog srodstva, jer nije jasno jesu li i sama posvojčad međusobno adoptivni srodnici. Osim toga, korištenje termina „srodstvo“ i „srodnici“ nije uvijek prilagođeno konkretnom sadržajnom kontekstu, jer se u nekim zakonima ne raspoznaje jasno na koju vrstu srodstva se misli - primjerice samo na krvno ili na sve vrste srodstva. ${ }^{5}$

3 Napominjemo da u ulozi posvojitelja može biti jedna ili dvije osobe, a u ulozi posvojenika jedna ili više osoba, što u samom jezičnom izričaju nije uvijek (pa i ovdje) vidljivo.

$4 \quad$ Važeći (obiteljski) zakoni u BiH poznaju dvije vrste posvojenja: potpuno i nepotpuno, $\mathrm{u}$ kojima je sadržaj i opseg adoptivnog srodstva različit.

Obiteljski zakon Republike Hrvatske (dalje: ObZ RH) od 2003. godine uređuje jedan oblik posvojenja istovjetan potpunom posvojenju u spomenutim zakonima $\mathrm{BiH}$ (u ObZ RH iz 1998. postojalo je srodničko i roditeljsko posvojenje). Jedan (isti) oblik posvojenja uređuje i Porodični zakon Republike Srbije (Službeni glasnik Republike Srbije, br. 18/2005, 72/2011 i 6/2015).

Primjeri za to:

- Čl. 113. st. 1. ObZ FBiH: „Potpunim posvojenjem se između posvojitelja i njegovih srodnika, $s$ jedne strane, i posvojčeta i njegovih potomaka, s druge strane, zasniva neraskidiv odnos srodstva jednak krvnom srodstvu."

- Čl. 4. st. 1. Zakona o nasljeđivanju u FBiH (SN FBiH, br. 80/2014): „Izvanbračno srodstvo izjednačuje se u pogledu nasljeđivanja s bračnim, a srodstvo potpunog posvojenja sa srodstvom po krvi." 


\section{Srodnički odnosi u kontekstu obiteljskog nasilja}

Nasilje u obitelji ${ }^{6}$ je društveno neprihvatljivo ponašanje članova obitelji koje se manifestira nanošenjem ozljeda, boli, zastrašivanja, vrijeđanja, spolnog i drugog uznemiravanja, izoliranja, materijalnog ili radnog iskorištavanja. ${ }^{7}$ Značajan je čimbenik slabljenja obitelji, ${ }^{8}$ kao i samoga društva. Javlja se između bliskih osoba u interakciji osjećaja intimnosti i sukoba interesa, ljubavi i mržnje, kao i posljedica kriza i transformacija društva koje se odražavaju i na obitelj. Iako granica između dobronamjernih napora roditelja da njihova djeca prihvate i poštuju moralne, kulturne i općecivilizacijske navike i vrednote, u odnosu na njihove stroge i neprimjerene postupke može ponekad biti minimalna, smatramo da je glavni problem u neadekvatnoj društvenoj zaštiti i postojanju mnoštva neotkrivenih slučajeva nasilja u obitelji. ${ }^{9}$

Nositelji prava na zaštitu od nasilja u obitelji su svi subjekti srodničkih odnosa (bez obzira na stupanj srodstva), odnosno svi članovi obitelji, ${ }^{10}$ a žrtve nasilja su najčešće djeca, nemoćni i ostarjeli članovi obitelji, te žene. ${ }^{11}$

Osim što su srodnički odnosi najzastupljeniji u pojavnosti nasilja u obitelji, ovdje je važno istaknuti da postoji određena društvena rezerviranost i blaga toleranci-

$6 \quad$ Nasilje u obitelji (engl. violence in the family; njem. Innerfamiliāre Gewalt; franc. violence familiale) predstavlja povredu temeljnih ljudskih prava, a može biti tjelesno ili duševno.

7 Tako: Pezo, V., (gl. ur.), Leksikografski zavod Miroslav Krleža, Zagreb, 2007., str. 788.

Po nekim istraživanjima stručnjaka za nasilje u zapadnim zemljama „... obitelj je uz policiju i vojsku najnasilnija društvena grupa", a kriminološka istraživanja u SAD-u iznose podatke da rođaci čine jednu četvrtinu do jedne trećine svih žrtava ubojstva, te da zlostavljanja djece znatno češće čine nebiološki roditelji. Kao i u drugim društvenim segmentima, nasilje u obitelji najčešće je posljedica naslijeđenih sklonosti, neprimjerene socijalizacije i patoloških uvjeta, koji nažalost nerijetko nadvladavaju obiteljsku bliskost i adaptaciju. Izvor: Kardum I., Evolucija i ljudsko ponašanje, Naklada Jesenski i Turk, Zagreb, str. 97. - 110.

9 Mnogovrsni oblici nasilja, zlouporabe, zlostavljanja djece itd., na određeni način su dovela do normiranja njihovih zabrana. Pravo na zaštitu od nasilja od roditelja i ostalih srodnika povezano je s pravima djeteta na zdravlje i s njegovim pravom na čast i ugled, sukladno čl. 16. Konvencije o pravima djeteta (1989.). Usp. Alinčić, M., Bakarić Abramović, A., Belajec, V., Hrabar, D., Hrvatin, B., Jakovac-Lozić, D., Korać, A., Obiteljski zakon: redakcijski pročišćen tekst zakona, uputama, sudskom praksom i pojmovnim kazalom: drugi izvori obiteljskog prava, Narodne novine, Zagreb, 2004., str. 144. - 149. Usp. čl. 380. st. 1. ObZ FBiH i čl. 288. st. 1. ObZ BD.

$\mathrm{Na}$ koji način roditeljski status žene (majčinstvo) ima učinke i na jačanje jednakopravnosti spolova i smanjivanje nasilja u obitelji v. kod: McGlynn, C., Ideologies of Motherhood in European Community Sex Equality Law, European Law Journal, Vol. 6 Issue 1, 2000, p 29-44. 
ja srodničkoga nasilja, čime se u mnogim slučajevima uočava društvena nebriga i nemiješanje $u$ interne obiteljske probleme. $U$ tom smislu naročito je izražena društvena inertnost glede roditeljskog nasilja nad djecom, a što je na određeni način posljedica tradicionalnog shvaćanja obitelji kao jedne zatvorene društvene skupine, koja „ima pravo" sama rješavati svoje probleme, a roditeljska skrb nad djecom često se shvaća kao ekskluzivno pravo u koje se društvo ne treba miješati. ${ }^{12}$

Društveno-pravna zaštita žrtava nasilja u obitelji uglavnom se ostvaruje obiteljskopravnim mjerama, kaznenim i prekršajnim progonom, kao i javnom osudom nasilničkog ponašanja.

Tri važeća obiteljska zakona u BiH izričito zabranjuju nasilničko ponašanje u obitelji, ${ }^{13}$ a ono je u ObZ FBiH definirano kao "svako narušavanje fizičkog ili psihičkog integriteta u smislu članka 4. Zakona o ravnopravnosti spolova u Bosni i Hercegovini”. ${ }^{4}$

Zaštita djece od nasilja u obitelji ostvaruje se i obiteljskopravnim zaštitnim mjerama. Roditelju koji zlouporabom svojih prava - u slučajevima tjelesnog i duševnog nasilja nad djetetom, spolnog iskorištavanja djeteta, navođenja djeteta na društveno neprihvatljivo ponašanje, te na druge načine grubog kršenja djetetovih prava očito stavlja u opasnost sigurnost, zdravlje ili moral djeteta, ili koji ne zaštiti dijete od ovakvog ponašanja drugog roditelja ili druge osobe; sud će $\mathrm{u}$ izvanparničnom postupku oduzeti roditeljsku skrb (čl. 154. st. 1. i 2. ObZ FBiH). Spomenut ćemo i odredbu čl. 127., kojom dijete u obitelji ima pravo na zaštitu od svih oblika nasilja, zloupotrebe, zlostavljanja i zanemarivanja, ${ }^{15}$ a roditelji su du-

12 Primjerice, i u SAD postoje drukčija vrednovanja i sankcioniranja i roditeljskoga nasilja nad djecom (tj. neprimjerena i blaža), poglavito tjelesnoga kažnjavanja djece, u odnosu na ostale oblike nasilja (u obitelji i općenito u društvu). O tome iscrpnije v. kod: Bollenbacher, V., Burt,S., Discipline, Assault, and Justice: Violent Parents and the Law, Law \& Policy, Vol. 19 Issue 3, 1997, p 343 - 361.

V. čl. 4. st. 1. ObZ FBiH; čl. 13. st. 3. PoZ RS; čl. 3. st. 1. ObZ BD.

Taj zakon je objavljen u Službenom glasniku BiH, br. 16/2003. Čl. 4. tog zakona uređuje što je nasilje na osnovi spola (st. 1. t. b.), uznemiravanje (st. 1. t. c) i seksualno uznemiravanje (st. 1. t. d). Međutim, držimo da je pojam nasilja u obitelji sadržajno širi problem i ne može se svesti samo na nasilje i uznemiravanje seksualne prirode. Stoga smatramo da bi postojeći članak 4. ObZ FBiH trebalo izmijeniti u smislu potrebe sadržajnog upućivanja na odredbe sada važećeg Zakona o zaštiti od nasilja u obitelji (SN FBiH, br. 20/2013. i $75 / 2021$.$) .$

ObZ FBiH predviđa i novčane kazne za pravnu osobu, odnosno ustanovu, ako ne izvijesti skrbničko tijelo o povredi dječjih prava, a naročito o nasilju, zlostavljanju, spolnim zlouporabama i zanemarivanju djeteta; te ako ne odstrani osobu koja se nasilnički ponaša ili od koje prijeti opasnost od nasilničkog ponašanja, a novčane kazne (od 500 do $3000 \mathrm{KM}$ ) su predviđene i za odgovorne osobe u pravnoj osobi odnosno ustanovi (usp. čl. 383. st. 1. i 2.). 
žni čuvati dijete od "ekonomske eksploatacije, seksualne zlouporabe i svih drugih asocijalnih pojava” (čl. 134. st. 2.).

Roditelju koji zloupotrebom svojih prava, grubim zanemarivanjem svojih dužnosti, napuštanjem djeteta ili neispunjavanjem dužnosti roditeljske skrbi prema djetetu s kojim živi - očito stavlja u opasnost sigurnost, zdravlje ili moral djeteta, ili koji ne zaštiti dijete od ovakvog ponašanja drugog roditelja ili druge osobe, sud će u izvanparničnom postupku oduzeti roditeljsku skrb (čl. 154. tog zakona). ${ }^{16}$

ObZ FBiH uređuje i posebni postupak zaštite od nasilničkog ponašanja u obitelji (čl. 380.-382.), kojim se propisuje tko ima pravo na zaštitu, nositelji zaštite, te žurnost postupka. Podrobnije uređivanje prepušteno je Zakonu o zaštiti od nasilja u obitelji.

Krug osoba koje čine obitelj uredio je i federalni Zakon o zaštiti od nasilja u obitelji, navodeći da iz kruga srodnika obitelj čine: djeca bračnih i izvanbračnih partnera (zajednička ili iz ranijih zajednica); krvni srodnici i srodnici iz odnosa potpunog posvojenja u ravnoj crti bez ograničenja, a u pobočnoj crti zaključno s četvrtim stupnjem; očuh, maćeha, posvojenik i posvojitelj iz odnosa nepotpunog posvojenja; tazbinski srodnici zaključno s drugim stupnjem, ${ }^{17}$ te djeca bivših bračnih i izvanbračnih partnera (zajednička ili iz ranijih zajednica) i njihovi roditelji, uključujući očuha i maćehu. ${ }^{18}$ Važno je naglasiti da ovdje navedeni krvni, adoptivni i tazbinski srodnici čine obitelj, neovisno o tome žive li zajedno. Naime, prema odredbama prethodno važećeg zakona, bilo je uređeno da srodnici moraju živjeti zajedno da bi se smatrali članom obitelji i uživali zaštitu od nasilja $\mathrm{u}$ obitelji. ${ }^{19}$ Tim recentnim vrednovanjem srodstvo je na određeni način u većoj mjeri dobilo na važnosti, odnosno obuhvat zaštite od obiteljskog nasilja nije ograničen samo na zajedničko življenje. Ratio legis ovakvog pristupa može se uočiti i u činjenici promjena u suvremenom načinu kontakata i komuniciranja, digitalizaciji, društvenim mrežama i sl., što ostavlja mogućnost boljoj kakvoći srodničkih i obiteljskih veza, ali i širem spektru pojavnih oblika njihovog narušavanja i ugrožavanja.

Ovim zakonom uređen je način zaštite, te vrsta i svrha sankcija za počinitelje nasilnih radnji. Zaštitu od nasilničkog ponašanja dužni su žurno pružiti policija, skrbničko tijelo i prekršajni sud, te druge institucije mjerodavne za socijalnu skrb

16 Kao razlog lišenja roditeljske skrbi, obiteljsko nasilje kao razlog naveden je u sva tri obiteljska zakona u $\mathrm{BiH}$, kao i u poredbenim propisima svih susjednih država.

Zakonodavac je ovdje ostao nedorečen, jer nije naveo na srodnike koje crte (ravne ili pobočne) drugoga stupnja se misli. S obzirom na prirodu i sadržaj pravnih učinaka tazbinskoga srodstva smatramo da se odredba odnosi (samo na) ravnu crtu. 
i zdravstvenu zaštitu, uz obvezu zajedničkog i koordiniranog djelovanja. (čl. 3. st. 2). U smislu tog zakona smatrat će se da postoji nasilje u obitelji ako postoji osnova sumnje da su učinjene radnje kojim član obitelji nanosi tjelesnu, psihičku ili seksualnu bol ili patnju i/ili ekonomsku štetu, kao i prijetnje koje izazivaju strah od tjelesnog, psihičkog ${ }^{20}$ ili seksualnog nasilja i/ili ekonomske štete kod drugog člana obitelji (čl. 7. st. 1. ), a zakon detaljno određuje i radnje nasilja u obitelji (čl. 7. st. 2.).

U ovom kontekstu spomenut ćemo i Zakon o zabrani diskriminacije ${ }^{21}$ koji definira pojam i navodi oblike diskriminacije, ${ }^{22}$ kao i postupanja javnih tijela, fizičkih i pravnih osoba na svim razinama i u svim područjima društvenog života u svrhu sprječavanja i zaštite od različitih oblika diskriminacije. Izmjenama ovog zakona srodnički odnosi dodatno su vrednovani, jer je pravni sadržaj diskriminacije prema bilo kojoj osobi ili društvenoj skupini u svom obuhvatu mogućih žrtava proširen i na one koji su s navedenim osobama ili pripadnicima skupine u rodbinskoj ili drugoj vezi. ${ }^{23}$

Kazneno djelo nasilje u obitelji uvedeno je u pravni sustav $\mathrm{BiH}$ 2003. godine. Odredbama čl. 222. st. 1. Kazneni zakon Federacije Bosne i Hercegovine (dalje: $\mathrm{KZ} \mathrm{FBiH})^{24}$ propisuje da "tko nasiljem, drskim ili bezobzirnim ponašanjem ugrožava mir, tjelesnu cjelovitost ili psihičko zdravlje člana svoje obitelji” kaznit će se novčanom kaznom ili kaznom zatvora do jedne godine. ${ }^{25}$ Zakon uređuje pet kvalificiranih oblika kaznenog djela, a poimenično navodi da su članovi obitelji iz kruga srodnika: krvni srodnik u ravnoj liniji, posvojitelj i posvojenik, krvni srodnik u pobočnoj liniji do trećeg stupnja zaključno i tazbinski srodnik do drugog stupnja zaključno. ${ }^{26}$

Podrobnije o ovom segmentu nasilja v. u: Krstinić, D., Vasiljković, J., Oblici nasilja u porodici, Pravo - teorija i praksa, br. 07-09, Novi Sad, 2019., str. 73. i 74. file://C:/Users/ Pc1/Documents/MOJ\%20RAD\%202021/Nasilje\%20u\%20obitelji/0352-37131907067K. pdf (20. 5. 2021.).

Objavljen u Službenom glasniku BiH (dalje: SG BiH), br. 59/2009 i 66/2016.

Zakon izričito navodi oblike diskriminacije: posredna, neposredna, uznemiravanje, spolno uznemiravanje, mobing, segregacija, poticanje na diskriminaciju.

Usp. čl. 1. Zakona o izmjenama i dopunama Zakona o zabrani diskriminacije (SG BiH, br. 66/2016).

Objavljen u SN FBiH, br. 36/2003, 37/2003, 21/2004, 69/2004, 18/2005,42/2010, 42/2011, 59/2014, 76/2014, 46/2016 i 75/2017.

Sadržajno iste odredbe sadržane su i u čl. 190. st. 1. Kaznenog zakona RS (SG RS, br. $64 / 2017,104 / 2018,15 / 2021$ i 89/2021) i u čl. 218. stav 1. i 2. Kaznenog zakona BD BiH (SG BD, broj 19/2020). ževni i razgovorni nego pravni termini. (Usp. čl. 2. Zakona). 


\section{Kaznenopravno vrednovanje srodstva u kontekstu zaštite života i obitelji}

Sukladno okvirnom prostoru, osvrnut ćemo se na odredbe KZ FBiH koje uređuju neka kaznena djela iz skupina: kaznenih djela protiv života i tijela (glava XVI); kaznenih djela protiv slobode i prava čovjeka i građanina (XVII); kaznenih djela protiv spolne slobode i ćudoređa (glava XIX) te kaznenih djela protiv braka, obitelji i mladeži (glava XX Zakona).

Povećana bliskost osoba u srodničkom odnosu rezultira i izraženijim stupnjem međusobnih prava i dužnosti, a narušavanje tih odnosa društvo je kroz povijest strože sankcioniralo. Posebice su strože kažnjavana djela protiv tjelesnog integriteta i života srodnika ${ }^{27}$ - primjerice u rimskom pravu postojao je poseban zakon koji je sankcionirao ubojstva između bliskih krvnih srodnika. ${ }^{28}$

Činjenica postojanja srodničke veze između određenih osoba u kaznenome pravu posebno se vrednuje ${ }^{29}$ i proizvodi specifične pravne učinke. Tako postoji dvojaka derogacija općih pravila kaznenoga prava zbog postojanja srodničkih odnosa glede odgovornosti za počinjeno djelo, na način pojačavanja ili ukidanja (ublažavanja) kaznene odgovornosti srodnika. Primjer pojačavanja kaznene odgovornosti za djelo učinjeno prema srodniku ${ }^{30}$ imamo kod kaznenog djela krvne osvete, rodoskvrnuća ${ }^{31}$ i spolnog odnosa zloupotrebom položaja; a za ubla-

$27 \quad$ Prema istraživanju o ubojstvima među srodnicima u razdoblju 140 godina prije pada Dubrovačke Republike, uz čedomorstvo, najveći broj ubojstva među krvnim srodnicima događao se među braćom (36), a ubojstva između roditelja i djece (13) učinjena su najčešće u nehaju. Usp. Vekarić, N., Ubojstva među srodnicima u Dubrovačkoj Republici: (1667. - 1806.), Anali Zavoda za povijesne znanosti i umjetnosti u Dubrovniku, Svezak 37, Zagreb-Dubrovnik, 1999., str. 103.

Prema tom zakonu „...odgovaraju oni koji ubiju oca, majku, djeda, baku, brata, sestru, patrona ili patronku; oni su ranije kažnjavani bacanjem u more zašiveni u vreću; sada pak bivaju živi spaljeni ili bačeni divljim zvijerima“. Međutim, treba naglasiti da je kazna ovisila o stupnju krivice počinitelja, jer je, osim najteže kazne, bilo moguće i osloboditi počinitelja ako je djelo počinio u nehaju, tj. bez namjere da izvrši ubojstvo. Usp: Paulo, J., Sentencije, Latina et Graeca, Zagreb, str. 233. i 277.

Za srodničke odnose i općenito kaznena djela između srodnika možemo kazati da vrijede opće zakonitosti društva. U mirnijim i stabilnijim vremenima jača srodnička (kao i) općedruštvena harmonija, u „...razdobljima beznađa broj (srodničkih) ubojstava raste, a u razdobljima nade opada.“ Izvor: Vekarić, N., op. cit., str. 138.

Još iz rimskog prava poznata je izreka: Vulnera cognatae sunt graviora manus - Rane (zadane) srodničkom rukom teže su. Izvor: Romac, A., Latinske pravne izreke, Zagreb, 1982., str. 83. 
ženu odgovornost kod kaznenih djela čedomorstva. Kaznena djela inače mogu biti propisana kao temeljna, kvalificirana ili privilegirana, ovisno o obilježjima koja ih čine težim ili lakšim, a s obzirom na krivnju mogu biti kvalificirana težom posljedicom ili naročitom okolnošću. ${ }^{32}$

Ukratko ćemo, sukladno važećim propisima, navesti značajnija kaznena djela između srodnika i ona koja mogu biti potaknuta srodničkom vezom.

\subsection{Neka kaznena djela protiv života i tijela}

Krvna osveta, odnosno ubojstvo iz krvne osvete, još uvijek egzistira kao povijesni relikt u sferi običajnog prava kod nekih naroda na jugoistoku Europe. Prožeta je etičkim, svjetonazorskim i psihološkim sadržajima, zato što podlogu osvete čini srodnička solidarnost i težnja za uspostavom narušene pravde i pravičnosti. Na tim postavkama su zagovornici osvete kao prirodnoga prava nalazili argumente za tvrdnju da je to moralno pravo i dužnost svakog čovjeka. ${ }^{33} \mathrm{Na}$ koji način srodnička povezanost remeti ili mijenja ${ }^{34}$ ustaljene društvene norme o zaštiti ljudskog života najočitije govori fenomen krvne osvete, kao specifičan oblik nasilja i kaznenog djela kojim se u pojedinim društvima brani javni „obraz“ roda odnosno srodnika. Ona je, u pravilu, izravni izraz agnatske solidarnosti i poprimila je institucionalni oblik ${ }^{35}$ kao krajnji vid nasilja - kada su najbliži agnatski srodnici ubijenog (braća i sinovi) dužni osvetiti smrt bilo kojeg svojeg člana tako što će samog ubojicu lišiti života.

Ubojstvo iz krvne osvete u kaznenopravnom smislu može ali ne mora uvijek biti teško ubojstvo. ${ }^{36}$ Člankom 166. st. 2 . t. d. KZ FBiH propisano je i ubojstvo „...

32 Podrobnije o tome v. u: Horović, S., Kazneno pravo Opći dio, knjiga I. (Pojam kaznenog prava, kazneno djelo i krivnja), Sveučilište u Mostaru, Mostar, 2020., str. 99. - 102. i 158. $-161$.

„Jer nagon osvete ... nije u svijesti, ona je po svojoj evoluciji starija od svijesti, ona je dakle u krvi“. Striković, J., Antropološka svojstva osvete i prirodno pravo, Pravni život, Beograd, 12/2003, str. 718 .

Koliko je važno javno mnijenje proisteklo iz srodničkih veza pokazuju i odredbe splitskog srednjovjekovnog statuta, u kojima se „...s velikim razumijevanjem gledalo čak i na krvnu osvetu..." Janeković - Römer, Z., Rodbinski odnosi u dalmatinskom društvu XIII. i XIV. stoljeća, Historijski zbornik, XLV (1) Zagreb, 1992., str. 188.

O specifičnom obliku krvne osvete („kisas") u sunitskom i šiitskom šerijatu v. podrobnije u: Krim, K., (gl. ur.), Enciklopedija živih religija 2. Fototipsko dopunjeno izdanje, Nolit, Beograd, 2004., str. 379. 
iz bezobzirne osvete..." ${ }^{37}$ koja postoji kada je prisutan očiti nesrazmjer između nanesenog zla koje je povod osveti i zla koje nastaje počinjenjem tog ubojstva. ${ }^{38}$

Čedomorstvo je definirano kao kazneno djelo kojim „Majka usmrti svoje dijete za vrijeme ili izravno nakon poroda “.$^{39}$ Ono je privilegirano kazneno djelo, ${ }^{40} \mathrm{zbog}$ svojstva počinitelja odnosno specifične srodničke uloge: majka rodilja - srodnički odnos i pravo odlučivanja o vlastitom porodu i utjecaj poremećaja pri porodu. ${ }^{41}$ Opis ovog kaznenog djela i zaprijećena kazna značajno su izmijenjeni u odnosu na odredbe prethodno važećeg $\mathrm{KZ} \mathrm{FBiH} .{ }^{42}$

Protupravni prekid trudnoće $e^{43}$ obuhvaća slučajeve započinjanja, učinjenja, te pomaganja pri protupravnom prekidu trudnoće. ${ }^{44}$ Ovdje možemo istaknuti bitan normativni nedostatak ovog kaznenog djela, zato što se, osim liječnika, nadriliječnika, primalje, ne predviđa i kaznena odgovornost za samu trudnicu kada

Ubojstvo iz krvne osvete može se svrstati u „bezobzirnu osvetu“. Krvna osveta je prerasla u običajno pravo, ona je socijalna kategorija (izvire iz srodničke zajednice), ne zastarijeva, itd. Detaljnije v. kod Šeparović, Z., Krivično pravo - Posebni dio (II), Zaštita čovjeka i njegovih vrijednosti, 1979., str. 30. - 36.

Detaljnije v. kod: Horović, S., Kazneno pravo (Posebni dio), Pravni fakultet Sveučilišta u Mostaru, Mostar, 2000., str. 54. - 57; Horović, S., Posebni dio kaznenog prava Bosne i Hercegovine, Knjiga II., Pravni fakultet Sveučilišta u Mostaru, Mostar, 2010., str. 24. - 25. Usp. čl. 169. st. 1. KZ FBiH. Radnja ovog kaznenog djela može se ostvariti činjenjem i nečinjenjem.

Uzroci i okolnosti čedomorstva - uglavnom izvanbračno rođene djece nisu se puno mijenjali kroz povijest. Ono je izraz „najneprihvatljiviji i uvijek osuđujući oblik razrješenja sukoba između prirodnog nagona, trenutka slabosti i tome suprotstavljene moralne norme. A majka, u posebnom psihičkom stanju nakon poroda, olako bi povjerovala u mogućnost prikrivanja“. Podrobnije v. kod. Vekarić, N., op. cit., str. 114.

Da taj poremećaj i nije presudan, govori sudska praksa po kojoj se i ubojstvo djeteta smišljeno unaprijed, prije poroda nije tretiralo kao obično ubojstvo.

Čl. 147. KZ FBiH (SN FBiH, br. 43/1998) uređivao je kazneno djelo „ubojstva djeteta pri porođaju“, zaprijećena kazna je zatvor od tri mjeseca do tri godine. U sadašnjem zakonu izostavljen je tekst „... dok traje poremećaj što ga je kod nje izazvao porođaj“, a zaprijećena je kazna zatvora od jedne do pet godina.

Smatramo ovdje potrebnim navesti terminološke razlike izraza: pobačaj i prekid trudnoće. Pobačaj ili abortus (lat. aboriri: propasti, umrijeti) znači izgon ili odstranjenje ploda iz maternice prije isteka 28 tjedana; a prekid trudnoće obuhvaća sve protupravne intervencije u trudnoću žene poduzete u svrhu prekida trudnoće, i one poslije navršenja 28 tjedana trudnoće. V. Hrvatska enciklopedija, Leksikografski zavod Miroslav Krleža, sv. 1, Zagreb, 1999., str. 12. 
se uz njezin pristanak obavlja, ${ }^{45}$ odnosno koja sama čini protupravni prekid trudnoće.

U monarhističkoj Jugoslaviji bilo je zabranjeno „prekidanje trudnoće i pobačaj", 46 a odgovarala je i sama trudna žena, da bi se 1951. godine ukinula kažnjivost trudne žene. Ustavom SFRJ iz 1974. godine,${ }^{47}$ te Zakonom o uslovima i postupku za prekid trudnoće ${ }^{48}$ ( $\mathrm{SR} \mathrm{BiH)} \mathrm{pobačaj} \mathrm{je} \mathrm{legaliziran} \mathrm{i} \mathrm{uz} \mathrm{određene} \mathrm{uvjete} \mathrm{dozvo-}$ ljen do navršenih deset tjedana trudnoće. ${ }^{49}$ Ne upuštajući se u rasprave o potrebi promjene tog zastarjelog zakona i neutemeljenosti takvog prava na pobačaj, ${ }^{50}$ moramo postaviti pitanje - što je s kaznenom odgovornosti žene (ali i muškarca - oca) koja dopušta ili sama čini prekid trudnoće nakon deset tjedana trudnoće bez zakonskih indicija, tj. kada čini kazneno djelo protupravnog prekida trudnoće. ${ }^{51}$ Jer, tko je pozvaniji od same majke da štiti nerođeno dijete i nakon isteka razdoblja trudnoće u kome je dozvoljen pobačaj, a spomenutom odredbom KZ $\mathrm{FBiH}$ protuzakonito samopobacivanje nije kazneno djelo.

45 Svakako treba istaknuti postojanje mnogih slučajeva neslaganja budućih roditelja o činu pobačaja. Znakovito je što se kao presudna volja uzima volja žene koja nosi dijete i hoće pobačaj, a otac nerođenog djeteta nema pravo zahtijevati rođenje djeteta protiv volje majke. Usp. presudu Europskog suda za ljudska prava u slučaju Paton v. United Kingdom (Appl. no. 8416/78; Judgment of 13 May 1980). Navodimo primjer sudske prakse u Republici Hrvatskoj, koji upućuje na nesumnjivu važnost i odgovornost muškarca za budući život - izvadak iz obrazloženja presude Županijskog suda u Koprivnici, RH, broj Gž- 847/05-2, od 2. lipnja 2005. godine: „... na temelju odredbe čl. 201. Zakona o obveznim odnosima ... naknada štete zbog smrti bliske osobe pripada roditeljima zbog smrti djeteta, pa, prema tome... i u slučaju gubitka ploda ...i tužitelju za koga sud pravilno utvrđuje da je on otac začetog a nerođenog djeteta." Preuzeto iz: Domaća i strana sudska praksa, god. III, br. 17, Sarajevo, 2006., str. 93. Šeparović, Z., op. cit., str. 51.

Čl. 191. glasi: „Pravo je čovjeka da slobodno odlučuje o rađanju djece. To se pravo može ograničiti samo radi zaštite zdravlja."

Objavljen u Službenom listu SR BiH, br. 29/1977. i 12/1987., a vrijedi i sada na prostoru $\mathrm{FBiH}$ i BD BiH.

Čl. 5. tog zakona.

U kojoj mjeri i kako uvažavati i balansirati pravo na slobodno roditeljstvo s pravom na život nerođenog djeteta? Je li ljudski zametak samo objekt, ili mu, kao, već sada ljudskom biću u razvoju treba pružiti veću zaštitu? Očito je da sadašnjim uređenjem u „sukobu interesa“ majke i nerođenog djeteta, dijete „je izvuklo deblji kraj, a da mu nije pružena mogućnost da se spase“. Usp. i v. podrobnije kod: Ponjavić, Z., Prekid trudnoće: pravni aspekti, „Nomos“ Beograd i Pravni fakultet Kragujevac, Kragujevac, 1997., str. 16. - 24., 81. - 100. i 177. - 194.

Prekid trudnoće u tom razdoblju bez zakonskih indicija i uz pristanak žene je kazneno djelo protupravnog prekida trudnoće. 
U sklopu razmatranja ovlasti odlučivanja, odnosno donošenja odluke o pobačaju, opravdano se može istaknuti zapostavljen položaj oca, odnosno njegove neravnopravnosti u odlučivanju. Čini se da je ovdje temeljno načelo obiteljskog prava - ravnopravnost žene i muškarca odnosno svih članova obitelji izgubljeno i zaboravljeno, posebice od udruga koje promiču (samo) ženska prava. ${ }^{52}$

U kaznenom djelu napuštanja nemoćne osobe ${ }^{53}$ nije izričito navedeno da se radi o srodnicima, ali se naslućuje da u velikom broju slučajeva briga o nemoćnim osobama, a onda često i napuštanje, može uključivati srodnički odnos. ${ }^{54}$

\section{2. Neka kaznena djela protiv slobode i prava čovjeka i građanina}

U sklopu srodničkih odnosa kazneno djelo otmice ${ }^{55}$ djelomično ima svoje pojavne oblike u otmici djece od roditelja, kao i kod otmice djevojke u svrhu sklapanja braka.

Odredbama čl. 180. st. 1. KZ FBiH propisano je da kazneno djelo otmice čini onaj „tko drugog protupravno zatvori, drži zatvorena ili mu na drugi način oduzme ili ograniči slobodu kretanja s ciljem da njega ili koga drugog prisili da što učini, ne učini ili trpi.... ${ }^{56}$

U suvremenim okolnostima česti su slučajevi međunarodnih otmica djece i drugih osoba. $\mathrm{BiH}$ je potpisnica Haške konvencije o građanskopravnim aspektima međunarodne otmice djece (1980.), ${ }^{57}$ koja svojim primarnim ciljem smatra osiguravanje što bržeg povratka djece protupravno odvedene ili zadržane u nekoj državi ugovornici. Konvencija odvođenje ili zadržavanje djeteta smatra protu-

52 Podrobnije o tome v. kod: Čolaković, M., Pravo na tjelesni integritet - privatnopravni aspekt, Univerzitet „Džemal Bijedić“ u Mostaru, Pravni fakultet, Mostar, 2015., str. 44. - 49. Čl. 176. st. 1. KZ FBiH glasi: “Tko nemoćnu osobu koja mu je povjerena ili o kojoj se je inače dužan brinuti ostavi bez pomoći u prilikama opasnim za život ili zdravlje...".

Postojanje zajamčene obveze između nemoćne osobe i mogućeg počinitelja svoje uporište može imati u zakonu - primjerice odnos roditelja i djece, ili u ugovoru - ugovor o doživotnom uzdržavanju.

Srodno ovom kaznenom djelu je i kazneno djelo oduzimanja djeteta ili maloljetnika (v. infra 4.4.).

Teži oblik ovog kaznenog djela predviđen je u čl. 180. st. 2. KZ FBiH („Tko kazneno djelo (...) počini prema djetetu ili maloljetniku..."), obuhvaća i slučajeve otmice djece od jednog roditelja kada on otmicom želi drugog roditelja prisiliti da što učini, ne učini ili trpi. Važi temeljem Zakona o ratifikaciji Konvencije o građansko-pravnim aspektima međunarodne otmice djece, Službeni list R BiH, br. 2/1992. i 13/1994., a Konvencija je objavljena u Službenom listu SFRJ - Međunarodni ugovori, br. 7/1991. 
pravnim ponajprije ako ono predstavlja povredu prava na skrb koje je osobi, ustanovi ili nekom drugom tijelu, zajednički ili pojedinačno, dodijeljeno na temelju prava države u kojoj je dijete imalo uobičajeno boravište prije samog odvođenja ili zadržavanja.$^{58}$ Konvencija se ne bavi kaznenopravnim pojmom otmice djece, ali značajno doprinosi zaštiti i ostvarivanju njihove skrbi putem bržeg vraćanja djece koju jedan roditelj odvede u drugu državu.

Kao specifičan izraz negacije individualnih prava unutar srodničkih odnosa kroz povijest je dugo egzistirala pojava otmice žena. Ona se obavljala u različitim situacijama i zbog više razloga, a jedan od najčešćih bio je kada otac djevojke ne daje pristanak na brak. Čin otmice bi stavio oca (roditelje) pred svršen čin, nakon čega bi uslijedilo izmirenje popraćeno isplaćivanjem cijene za djevojku i davanjem oproštaja od djevojčine rodbine. Otmica je postojala u mnogim narodima od najranijih vremena, a i na našim prostorima još i danas ima živih osoba bračnih partnera koji su sklopili brak nakon otmice djevojke. ${ }^{59}$

Paradoks otmice kroz povijest ogledao se i u različitim stajalištima društvenih čimbenika i rodbine prema njoj - od one negatorske kojom se otmica kažnjavala raskidom veze bračnih parova i vraćanjem žene rodbini odakle je silom istrgnuta; do one afirmativne, kada je otmica bila sredstvo mužu da se oslobodi žene, bratu da izbaštini sestru, a ocu da se oslobodi velikih troškova svadbe. Važnost rodbine kao sudionika ili (su)aktera otmice ogledala se često u dogovornoj ili prividnoj otmici. ${ }^{60}$ Naime, često bi otmica stvarno predstavljala reduciranu svadbu sa smanjenim brojem običajnih radnji, a obavljala se uglavnom uz pomoć i nazočnost uže rodbine nevjeste i ženika, koja je činila (improvizirane) svatove.

\subsection{Neka kaznena djela protiv spolne slobode i ćudoređa}

Kazneno djelo spolnog odnosa zloupotrebom položaja odnosi se na situacije psihičke prisile od aktivnog subjekta, a koji koristi stanje ovisnosti ili podređe-

$58 \quad$ Usp. čl. 3. st. 1. t. a) Konvencije.

59 U nekim hercegovačkim selima i selima Dalmatinske zagore i danas ima živih sudionika otmica, odnosno bračnih partnera koji su brak sklopili nakon otmice (tzv. „umicanja“) djevojke. Najčešći razlozi za takve otmice bili su: protivljenje djevojčine ili mladićeve rodbine tom braku, neodlučnost djevojke ili postojanje više prosaca, izbjegavanje troškova i ceremonije svatova, i sl.

Otmica djevojke u svakom slučaju ima dodirnih elemenata s kaznenim djelom otmice (koje se izvršava kada se „...drugog protupravno zatvori, drži zatvorena ili mu na drugi način oduzme ili ograniči slobodu kretanja s ciljem da (se) njega ili koga drugog prisili da što učini, ne učini ili trpi..." - čl. 180. KZ FBiH), a je li prigodom otmice djevojke nastalo i kazneno djelo u svakom slučaju ponajviše ovisi o (ne)pristanku djevojke na otmicu, odnosno sklapanje braka. 
nosti pasivnog subjekta. Zakonskom odredbom izvršitelj može biti i „... roditelj, ${ }^{61}$ posvojitelj, skrbnik, očuh, maćeha ...", 62 a zbog bliskosti postojećih odnosa i njihovom narušavanju ovim činom za ovo kazneno djelo propisana je pojačana kaznena odgovornost.

Intencija normiranja kaznenog djela rodoskvrnuća ${ }^{63}$ je održavanje poželjne strukture ljudske zajednice, ${ }^{64}$ a njega zabranjuju saznanja i empirijsko iskustvo da on vodi k degeneraciji potomstva. ${ }^{65}$ Ta zabrana je $u$ suvremenoj civilizaciji prepoznata i vrednovana kao prirodna i neupitna.

Već u rimskom pravu rodoskvrnuće je tretirano kao teško kazneno djelo, ${ }^{66}$ koje se u nekim slučajevima kažnjavalo i smrtnom kaznom. U okrilju Katoličke crkve zabrana rodoskvrnuća formulirana je u IX. stoljeću i nakon toga pod utjecajem kanonskog prava rodoskvrnuće se tretira kao kazneno djelo protiv morala i obiteljskih odnosa.

Važno je naglasiti da ovo kazneno djelo obuhvaća srodničke veze bračnog i izvanbračnog, te punorodnog i polurodnog krvnog srodstva. ${ }^{67}$

\subsection{Neka kaznena djela protiv braka, obitelji i mladeži}

Iz ove skupine kaznenih djela ukratko ćemo spomenuti djela u kojima su počinitelj i oštećenik u srodničkom odnosu ili kojim se bitno narušavaju

61 Počinjenjem ovog djela roditelj čini i kazneno djelo rodoskvrnuća.

62 Čl. 205. st. 2. KZ FBiH.

Prema odredbama čl. 213. KZ FBiH, kazneno djelo rodoskvrnuće čini „tko izvrši spolni odnošaj ili s njim izjednačenu spolnu radnju s krvnim srodnikom u ravnoj liniji ili s bratom ili sestrom" (st. 1.); ako to djelo počini s maloljetnikom (st. 2.); ili s djetetom (st. 3.).

O aktualnim dvojbama u kojoj mjeri su zaštita zdravih obiteljskih odnosa, odnosno ćudoređe objekt zaštite ovog kaznenog djela, v. u: Horović, S., Posebni dio kaznenog..., op. cit., str. 94.

65 Utvrđeno je da su učestalije neke bolesti (npr. albinizam, epilepsija, mentalna retardacija, nanizam, koronarna bolest srca itd.) u potomstvu roditelja koji su međusobno u krvnom srodstvu.

„Ako se radi o djelu rodoskvrnuća, muškarcu se određuje kazna izgnanstva na otok, dok se ženi djelo oprašta, ali samo onda kad ono nije obuhvaćeno Julijevim zakonom o preljubu“ - Paulo, J., op. cit., str. 111.

O kaznenom djelu rodoskvrnuća v. praksu Europskog suda za ljudska prava: Pretty v. the United Kingdom, no. 2346/02 (Sect. 4), (29. 4. 2002.); Sommerfeld v. Germany (Appl. no. 31871/96; Judgment of 8 July 2003); Zaunegger v. Germany, no. 22028/04 (Sect. 5) (3. 12. 2009.); Gäfgen v. Germany, no. 22978/05, (1. 6. 2010.); Öneryıldız v. Turkey, no. 48939/99, (30. 11. 2004.); Evans v. the United Kingdom, no. 6339/05, (10. 4. 2007.). 
srodnički odnosi: oduzimanje djeteta ili maloljetnika, ${ }^{68}$ promjena obiteljskog stanja; ${ }^{69}$ zapuštanje ili zlostavljanje djeteta ili maloljetnika; ${ }^{70}$ napuštanje djeteta; ${ }^{71}$ povreda obiteljskih obveza; ${ }^{72}$ nasilje u obitelji; ${ }^{73}$ izbjegavanje uzdržavanja. ${ }^{74}$

Počinitelj kaznenog djela oduzimanja djeteta ili maloljetnika može biti bračni i izvanbračni roditelj, samo jedan ali i oba roditelja, kao i druga osoba. ${ }^{75}$ Izvršenje ovog djela obično se događa u situaciji pred sam razvod ili nakon razvoda braka, kada jedan (ili oba) roditelj nije u mogućnosti izvršavati svoja prava prema djeci, a ona se nalaze obično kod drugog roditelja ili u odgovarajućoj ustanovi za smještaj i odgoj. ${ }^{76}$

Kazneno djelo promjene obiteljskog stanja izvršava $\mathrm{se}^{77}$ podmetanjem - lažnim prikazivanjem da je dijete rodila žena koja ga stvarno nije rodila; zamjenom lažnim prikazivanjem da je žena rodila neko dijete koje je stvarno rodila druga žena; ili drugom promjenom obiteljskog statusa djeteta. Spomenutim radnjama mijenja se pripadnost određenoj, pravoj obitelji i zajednici, te gube prava i obveze koja djetetu stvarno pripadaju - srodnički odnosi, obiteljsko ime, nasljedna prava.

Počinitelj ovog kaznenog djela je „tko dijete ili maloljetnika protupravno oduzme roditelju, posvojitelju, skrbniku ili osobi kojoj je povjeren, ili tko ga protupravno zadržava ili sprječava da bude s osobom koja ima to pravo ili tko onemogućava izvršenje ovršne odluke o skrbi prema djetetu ili maloljetniku." (čl. 217. st. 1. KZ FBiH). Usp. čl. 218. KZ FBiH. Čl. 219. KZ FBiH. Počinitelji mogu biti: roditelj, posvojitelj, skrbnik... V. čl. 220. KZ FBiH. Čl. 221. KZ FBiH. Povreda obiteljskih obveza odnosi se na člana obitelji koji nije u stanju sam o sebi skrbiti.

Nasiljem, drskim ili bezobzirnim ponašanjem ugrožava se mir, tjelesna cjelovitost ili duševno zdravlje člana svoje obitelji s kojim živi (ili ne živi) u zajedničkom kućanstvu - čl. 222. KZ FBiH. Čl. 223. KZ FBiH. V. detaljnije u: Horović, S., Posebni dio kaznenog..., op. cit., str. 102. i 103. O otmici, odnosno odvođenju i protupravnom zadržavanju djece s međunarodnopravnim elementom v. kod: Jakovac-Lozić, D., Međunarodne otmice djece od strane roditelja, Zbornik radova Pravnog fakulteta u Splitu, (45-46), 1-2 (1997.), str. 73. - 96. Za ovo kazneno djelo potrebna je umišljajna odgovornost (namjera), a ono se obično događa u rodilištima. 


\section{Zaključak}

Srodnički odnosi sadrže biološku i/ili društvenu sastavnicu koje se očituju kroz zajedništvo života i višestruku povezanost - biološku, emocionalnu, psihološku, ekonomsku, interesnu, etičku... Uređujući srodnička prava i dužnosti, zakonodavac istodobno štiti te odnose, nastojeći zadržati njihovu stalnost i kakvoću, a time i stabilnost odnosa u cijelom društvu. Međutim, zbog životnih problema, društvenih poremećaja i prirode ljudskog bića, srodnički odnosi su podložni devijaciji i transformiranju u destruktivne odnose. Stoga zakonodavci s posebnom pažnjom vrednuju, tretiraju i sankcioniraju pojedine postupke i radnje unutar obitelji i srodničkih odnosa, dajući im svojstva privilegiranih ili kvalificiranih oblika kaznenih djela. U domaćem kaznenom zakonodavstvu takva djela u kojima počinitelji mogu biti i srodnici možemo naći u sklopu sljedećih skupina: kaznena djela protiv života i tijela; kaznena djela protiv slobode i prava čovjeka i građanina; kaznena djela protiv spolne slobode i ćudoređa; te kaznena djela protiv braka, obitelji i mladeži. Intencija specifičnog zakonodavčeva pristupa je na odmjeren način zaštititi, sačuvati i ojačati društvene vrijednosti unutar srodstva kao kohezivnog čimbenika obitelji i društva.

Slojevitost srodničkih odnosa, bliskost i zajedništvo osoba ponekad mogu biti poremećeni ili narušeni grubim i pogubnim ponašanjem, čak izraženijim nego kod drugih oblika ljudske povezanosti. Analizom nekih kaznenih djela u domaćem zakonodavstvu utvrdili smo da je zakonodavčev pristup takvim radnjama dosta odmjeren, ali držimo da bi de lege ferenda trebala još odlučnija i stroža normativna zaštita biološke i društvene sastavnice srodstva kao kohezivnih elemenata obitelji i društva.

Razmatrajući problematiku obiteljskog nasilja, uočili smo da njegovo određenje i sankcioniranje nije ujednačeno u važećim zakonima. Isto tako definicije obitelji, odnosno krug srodnika koji je obuhvaćen prekršajnom i kaznenom zaštitom je različit u pojedinim zakonima. Osim toga, u navođenju pojedinih oblika srodstva nije precizirano na koju vrstu srodstva se misli. Stoga je potrebno ujednačavanje, posebno na svakoj zakonodavnoj razini (državna razina, entiteti i Brčko Distrikt), kao i između svih međusobno.

Jedna od glavnih funkcija obitelji je omogućavanje nastanka novog života, nove osobe i novog subjekta pravnih odnosa. Da bi mogao nastati subjekt, potreban je simbolički obiteljski poredak, koji pretpostavlja postojanje razlika, uloga i položaja za svakog pojedinca, koje proizlaze iz veza životnog zajedništva, krvnog, tazbinskog i adoptivnog srodstva, dobi ili spola. Obitelj od svih ostalih društvenih skupina izdvaja činjenica da ona puninu ostvaruje rođenjem novog ljudskog 
bića, odnosno posvojenjem kada se oponaša biološka veza. Time se srodstvo uspostavlja temeljem stvarnog ili zamišljenog podrijetla od zajedničkog pretka, taj odnos je trajan i nadilazi živote pojedinaca i naraštaja, pa možemo kazati da srodstvo ima nadvremenski status.

Možemo zaključiti da je srodstvo konstanta obiteljskih i širih društvenih odnosa i da u svim pojavnim oblicima štiti pojedinca i ljudski život, a kroz zajedništvo i solidarnost čuva i promiče temeljne ljudske i društvene vrijednosti. Stoga učinkovita zaštita i sankcioniranje nasilja i kaznenih radnji unutar obitelji i srodničkih odnosa ujedno predstavljaju važan mehanizam promicanja vrijednosti ljudskog života i jamac su ostvarenja dobrobiti pojedinca i opstanka cijelog društva.

\section{LEGAL APPROACHES AND EVALUATION OF KINSHIP IN THE CONTEXT OF DOMESTIC VIOLENCE AND SOME CRIMINAL ACTS IN BOSNIA AND HERZEGOVINA}

Summary: Kinship is the constitutional element of family structure, and to a substantial degree its determining factor. By its layered biological and social composition, it determines nature and characteristics of family and wider society in a special way. Kinship and family relationships are marked by solidarity, emotional closeness, interdependence and trust. These connection forms mostly have protective function, and they are a stability factor of family and wider social relationships, but sometimes they result into specific forms of violent behavior and some criminal acts.

In this paper, the authors analyze the existing normative approaches to the problems of domestic violence and some criminal acts, which threaten family unity and personal rights either directly or indirectly. They notice how family relationships sometimes contain elements of deviation and modification into destructive relationships due to life hardships and complex nature of human beings. They cite the efforts of legislators to evaluate and sanction actions and deeds within kinship and family relationships with special care, by giving certain actions the properties of privileged or qualified forms of criminal acts.

Intending to improve the protection of family and human life, within the topic, the authors also cite some suggestions de lege ferenda.

Key words: kinship and family; domestic violence; some criminal acts; protection of human life, family and society. 